\title{
EVALUASI MANAJEMEN PEMBELAJARAN DI MADRASAH
}

\author{
${ }^{1}$ Putriani L. Maliki, ${ }^{2}$ Alfian Erwinsyah \\ ${ }^{1}$ IAIN Sultan Amai Gorontalo, Jl. Sultan Amai, Gorontalo, Indonesia \\ email: alfian erwinsyah@iaingorontalo.ac.id \\ ${ }^{2}$ IAIN Sultan Amai Gorontalo, Jl. Sultan Amai, Gorontalo, Indonesia \\ email: alfian_erwinsyah@iaingorontalo.ac.id
}

\begin{abstract}
The purpose of this study is to describe the evaluation of learning management about learning management in Madrasah Tsanawiyah Negeri 1 Gorontalo City, to describe the inhibiting factors for the successful implementation of learning in Madrasah Tsanawiyah Negeri 1 Gorontalo City, and to describe the evaluation of learning in Madrasah Tsanawiyah Negeri 1 Gorontalo City. This research is categorized as a descriptive evaluative research with the approach used is a quantitative approach. Sources of data in this evaluation study came from: 1) documents that are administrative requirements of a program, 2) questionnaires (questionnaires) distributed to informants (students, principals, and teachers), and 3) interviews with the three informants. Data collection techniques used were questionnaire, observation, interview and documentation. While the data analysis technique used in this study is descriptive analysis of percentages. The results of this study indicate that overall learning management in Madrasah Tsanawiyah Negeri 1 Gorontalo City is classified as good, viewed from the aspect of learning planning, then followed by the implementation of learning until the evaluation of learning is classified successfully applied and beneficial to students in Madrasah Tsanawiyah Negeri 1 Gorontalo City especially in educators and grade VII and VIII students. Good criteria from the results of this study indicate that learning management is expected to be in accordance with the content standards in the curriculum in reality, namely in accordance with the stages of student development and conformity to the environment, as well as national development needs. Besides that learning management is planned, systematic and directed and is based on clear objectives. This can be seen from the planning / preparation of learning conducted by the teacher in the form of syllabus and lesson plans, implementation of learning that has been successful and good assessment / learning outcomes.
\end{abstract}

Keywords: Evaluation, Learning Management

\section{PENDAHULUAN}

Pembelajaran adalah upaya guru dalam mendesain instruksional, menyelenggarakan kegiatan belajar-mengajar atau membelajarkan, mengevaluasi hasil belajar yang berupa hasil pengajaran. Seorang pendidik harus memiliki keterampilan dalam pengelolaan pembelajaran yang meliputi tiga tahap kegiatan diantaranya membuat perencanaan pembelajaran, melakukan proses pembelajaran, dan melaksanakan evaluasi pembelajaran. Rencana pembelajaran merupakan dasar bagi peserta didik menerima pengalaman belajar di kelas. ${ }^{1}$ Perencanaan pembelajaran meliputi

${ }^{1}$ Darsono. Belajar dan Pembelajaran. Semarang : IKIP Semarang Press. 2000, h. 15 
penataan guru (pendidik), peserta didik dan tenaga administrasi, penggunaan metode, material, prosedur yang merupakan unsur-unsur perangkat pembelajaran yang harus terorganisasi secara sistematis dan sistemik. ${ }^{2}$ Pelaksanaan pembelajaran dikatakan berhasil apabila dapat mencapai tujuan yang telah ditetapkan dalam perencanaan. Pelaksanaan yaitu kegiatan memadukan atau mengintegrasikan sumber/potensi yang ada atau yang dapat disediakan kedalam rangkaian kegiatan yang telah direncanakan secara sistematis dalam rangka mencapai tujuan, meliputi: sumber daya manusia (yaitu peserta didik, pendidik dan sumber belajar lainnya), tujuan belajar, bahan belajar, alat/media belajar, tempat belajar, fasilitas atau sarana prasarana pendukung lainnya. Evaluasi dalam pembelajaran merupakan penetapan nilai. ${ }^{3}$ Evaluasi bertujuan untuk mendapatkan informasi yang akurat mengenai tingkat pencapaian tujuan pembelajaran oleh peserta didik sehingga pendidik dapat mengupayakan tindak lanjutnya. Keberhasilan pencapaian tujuan pembelajaran dapat dilihat dari hasil belajar siswa. Hasil belajar siswa tersebut diperoleh setelah proses pembelajaran berlangsung. ${ }^{4}$

Berdasarkan observasi awal sesuai dengan wawancara yang dilakukan penulis, berdasarkan informasi yang didapat dari salah satu guru di Madrasah Tsanawiyah Negeri 1 Kota Gorontalo, diketahui kenyataan bahwa di Madrasah Tsanawiyah Negeri 1 Kota Gorontalo memiliki beberapa keunggulan diantaranya dalam bidang pemahaman agama Islam, khususnya dalam hal disiplin ibadah dan pembelajaran aritmatika sempoa. Fenomena tersebut membawa penulis untuk menelaah manajemen pembelajaran dalam proses pendidikannya. Hasil studi diatas diperoleh fakta yang bagus yaitu adanya manajemen pembelajaran yang menekankan penerapan sikap disiplin pada siswa untuk mengimplementasikan hasil pembelajaran, bukan hanya itu tetapi juga didukung dengan manajemen pembelajaran yang menekankan pada tiga domain yaitu: Kognitif, afektif dan psikomotorik. Hasilnya sudah tentu menjadikan Madrasah Tsanawiyah Negeri 1 Kota Gorontalo ini memiliki keunggulan dalam hal pengetahuan, pemahaman dan penerapan mengenai pelajaran yang diajarkan. Sementara itu, sesuai yang ada di lapangan, diperoleh data bahwa pelaksanaan manajemen pembelajaran di Madrasah Tsanawiyah Negeri 1 Kota Gorontalo masih memperlihatkan ketidaksiapan baik personal, sarana prasarana, serta belum optimalnya pelaksanaan proses pembelajaran, sehingga mempengaruhi hasil belajar peserta didik. Berdasarkan alasan di atas penulis tertarik untuk mengadakan penelitian dengan judul "Evaluasi Manajemen Pembelajaran di Madrasah Tsanawiyah Negeri 1 Kota Gorontalo (Studi Evaluatif Model CIPP)".

\footnotetext{
${ }^{2}$ Majid, Abdul. Perencanaan Pembelajaran: Mengembangkan Standar Kompetensi Guru. Bandung: PT. Remaja Rosdakarya Offset. 2011, h. 45

${ }^{3}$ Syaiful Sagala. Konsep dan Wacana Pembelajaran. Bandung: Alfabeta, 2013, h. 33

${ }^{4}$ Widoyoko, Eko Putro. Evaluasi Program Pembelajaran; Panduan Praktis Bagi Pendidik dan Calon Pendidik. Yogyakarta: Pustaka Pelajar. 2011, h. 56
} 


\section{Hakikat Evaluasi}

Menurut Brinkerhoff, evaluasi merupakan proses yang menentukan sejauh mana tujuan pendidikan dapat dicapai. Dalam pelaksanaan evaluasi ada tujuh elemen yang harus dilakukan, yaitu 1) penentuan fokus yang akan dievaluasi (focusing the evaluation), 2) penyusunan desain evaluasi (designing the evaluation), 3) pengumpulan informasi (collecting information), 4) analisis dan interpretasi informasi (analyzing and interpreting), 5) pembuatan laporan (reporting information), 6) pengelolaan evaluasi (managing evaluation), dan 7) evaluasi untuk evaluasi (evaluating evaluation). ${ }^{5}$

Ralph Tyler menyatakan bahwa evaluasi merupakan sebuah proses pengumpulan data untuk menentukan sejauh mana, dalam hal apa, dan bagian mana tujuan pendidikan sudah tercapai. ${ }^{6}$

Dari beberapa definisi evaluasi di atas dapat ditarik kesimpulan bahwa evaluasi adalah proses yang sistematis dan berkelanjutan untuk mengumpulkan, mendeskripsikan, mengintepretasikan dan menyajikan informasi untuk dapat digunakan sebagai dasar membuat keputusan, menyusun kebijakan maupun menyusun program selanjutnya.

\section{Tujuan Evaluasi}

Secara umum, tujuan evaluasi pembelajaran adalah untuk mengetahui keefektifan dan efisiensi sistem pembelajaran, baik tujuan, materi, metode, media, sumber belajar, lingkungan maupun sistem penilaian dan ntuk menghimpun bahan keterangan (data) yang dijadikan sebagai bukti mengenai taraf kemajuan peserta didik dalam mengalami proses pendidikan selama jangka waktu tertentu.

Sedangkan secara khusus tujuan evaluasi pendidikan menurut Gronlund yaitu memberikan klarifikasi tentang sifat hasil pembelajaran yang telah dilaksanakan, memberikan informasi tentang ketercapaian tujuan jangka pendek yang telah dilaksanakan, memberikan masukan untuk kemajuan pembelajaran, memberikan informasi tentang kesulitan dalam pembelajaran, dan untuk memilih pengalaman pembelajaran pada masa yang akan datang. ${ }^{7}$

\section{Model-Model Evaluasi ${ }^{8}$}

Model evaluasi merupakan desain evaluasi yang dikembangkan oleh para ahli evaluasi, yang biasanya dinamakan sama dengan pembuatnya atau tahap evaluasinya. Berikut akan diuraikan

\footnotetext{
${ }^{5}$ Widoyoko, Eko Putro. (2011). Evaluasi Program Pembelajaran; Panduan Praktis Bagi Pendidik dan Calon Pendidik, h. 78

${ }^{6}$ Purwanto. Evaluasi Hasil Belajar. Yogyakarta: Pustaka Pelajar, 2009, h 29

${ }^{7}$ Purwanto. Evaluasi Hasil Belajar, h. 34

${ }^{8}$ Elis Ratnawulan dan Rusdiana. Evaluasi Pembelajaran. Bandung: Pustaka Setia, 2015, h. 37
} 
beberapa model evaluasi yang dikembangkan oleh para ahli dalam mengevaluasi program pembelajaran, yaitu sebagai berikut :

\section{a. Evaluasi Model Kirkpatrick}

Evaluasi model Kirkpatrick dalam implementasi bidang program pembelajaran perlu dikombinasikan karena adanya perbedaan karakteristik kegiatan pembelajaran di sekolah dan kegiatan pembelajaran dalam program training. Perbedaan karakteristik tersebut terletak pada karakteristik peserta dan aspek kegiatan belajar.

\section{b. Evaluasi Model CIPP (Context, Input, Process, and Product)}

Evaluasi model CIPP merupakan model yang paling banyak dikenal dan digunakan oleh para evaluator. Evaluasi model CIPP pertama kali dikenalkan oleh Stufflebeam dengan pandangan bahwa tujuan penting evaluasi adalah bukan hanya sekedar membuktikan tetapi untuk memperbaiki. Evaluasi model CIPP dapat diterapkan dalam berbagai bidang, seperti pendidikan, manajemen, perusahaan, dan sebagainya serta dalam berbagai jenjang baik itu proyek, program maupun institusi.

Dalam bidang pendidikan evaluasi model CIPP tergolong dalam empat dimensi yang menjadi sasaran evaluasi program kegiatan, yaitu context, input, process dan product. Komponen tersebut kemudian dikenal dengan singkatan CIPP.

\section{c. Evaluasi Model EKOP (Evaluasi Kualitas \& Output Pembelajaran)}

Evaluasi model EKOP merupakan modifikasi dari model Kirkpatrick dan model CIPP. Model ini menggunakan pendekatan penilaian proses dan hasil. Penilaian proses pembelajaran dalam hal ini disebut dengan penilaian kualitas pembelajaran, sedangkan penilaian hasil pembelajaran dibatasi penilaian output pembelajaran.

\section{d. Evaluasi Model Stake}

Stake menekankan adanya dua dasar kegiatan dalam evaluasi yaitu description dan judgement. Program pendidikan dibedakan menjadi tiga tahap yaitu antecedent (context), transaction (process) dan outcomes. Stake juga mengatakan bahwa apabila kita menilai suatu program pendidikan, kita melakukan perbandingan yang relative antara program dengan program yang lain, atau perbandingan yang absolute yaitu membandingkan suatu program dengan standar tertentu.

\section{e. Evaluasi Model Glaser}

Menurut Glaser ada 6 (enam) langkah yang dilalui dalam menilai program pengajaran, yaitu (1) mengidentifikasi hasil belajar, hendaknya dirumuskan dalam bentuk tingkah laku sehingga menunjukkan keterampilan-keterampilan yang harus diperoleh oleh siswa; (2) mendiagnosis kemampuan awal, menunjukkan pada kemampuan prasyarat yang diperlukan sebagai dasar bagi pengetahuan atau keterampilan yang akan dipelajari; (3) menyiapkan alternative pengajaran; (4) mengadakan pemantauan terhadap penampilan siswa, agar dapat diperoleh balikan 
yang segera dapat digunakan sebagai bahan perbaikan sebelum terjadi kesalahan yang berkelanjutan; (5) menilai ulang terhadap alternative pengajaran; (6) menilai dan mengembangkan pengajaran, sehingga diharapkan terjadinya evaluasi formatif atau mengumpulkan umpan balik demi pelaksanaan program pengajaran.

\section{Hakikat Manajemen Pembelajaran}

Menurut George R. Terry manajemen adalah suatu proses atau kerangka kerja yang melibatkan bimbingan atau pengarahan suatu kelompok orang-orang ke arah tujuan-tujuan organisasional atau maksud-maksud yang nyata. Sedangkan menurut Mary Parker Follet, manajemen merupakan seni dalam menyelesaikan pekerjaan melalui orang lain. Definisi ini mengandung arti bahwa para manajer mencapai tujuan-tujuan organisasi melalui pengaturan orang lain untuk melaksanakan berbagai tugas yang mungkin diperlukan, atau berarti dengan tidak melakukan tugas-tugas itu sendiri. ${ }^{9}$

Berdasarkan pendapat para ahli diatas, dapat disimpulkan bahwa manajemen adalah suatu seni mengelola yang dilakukan oleh pimpinan (manajer) dimulai dari perencanaan, pengorganisasian, pelaksanaan dan pengendalian menjadi suatu rangkaian kegiatan nyata dengan memanfaatkan semua sumber daya yang terkait untuk mencapai tujuan organisasi yang sudah ditetapkan sebelumnya secara efektif dan efisien.

Dimyati dan Mudjiono menyatakan bahwa "Pembelajaran adalah upaya guru dalam mendesain instruksional, ${ }^{10}$ menyelenggarakan kegiatan belajar-mengajar atau membelajarkan, mengevaluasi hasil belajar yang berupa hasil pengajaran". ${ }^{11}$

Hamalik menyatakan "Pembelajaran adalah suatu kombinasi yang tersusun meliputi unsurunsur manusiawi, material, fasilitas, perlengkapan dan prosedur yang saling mempengaruhi untuk mencapaitujuan pembelajaran". ${ }^{12}$

Dari beberapa pendapat di atas maka dapat disimpulkan definisi pembelajaran adalah usaha guru membentuk tingkah laku yang diinginkan dengan menyediakan lingkungan dan memberikan kebebasan kepada siswa untuk memilih bahan pelajaran dan cara mempelajarinya sesuai dengan minat dan kemampuannya, sehingga siswa lebih mudah mengorganisirnya menjadi pola yang bermakna untuk mencapai tujuan pembelajaran.

Sesuai dengan perkembangan kebutuhan manuia, pemahaman tentang manajemen seolah menjadi kekuatan yang utama dalam sebuah kegiatan organisasi sebagai suatu sistem menyeluruh untuk mencapai tujuan-tujuan organisasi secara efektif dan efisien termasuk halnya perkembangan kebutuhan manusia dalam ranah pendidikan yaitu pada manajemen pembelajaran. Berdasarkan pemikiran tersebut manajemen pembelajaran dalam arti sempit diartikan sebagai kegiatan yang

\footnotetext{
${ }^{9}$ Darsono. Belajar dan Pembelajaran. Semarang : IKIP Semarang Press, 2000, h. 87

${ }^{10}$ Dimyati dan Mudjiono. Belajar dan Pembelajaran. Jakarta : Rineka Cipta, 2002, h.75

${ }^{11}$ Hamalik, Oemar, Kurikulum dan Pembelajaran, Jakarta : Bumi Aksara, 1995, h. 45

${ }^{12}$ Darsono.Belajar dan Pembelajaran. h. 142
} 
perlu dikelola oleh guru selama terjadinya proses interaksinya dengan siswa dalam pelaksanaan pembelajaran. Sedangkan dalam arti luas manajemen pembelajaran berisi proses kegiatan mengelola bagaimana membelajarkan si pelajar dengan kegiatan yang dimulai dengan perencanaan, pengorganisasian, pengarahan, pengendalian dan penilaian. ${ }^{13}$

Manajemen pembelajaran menurut Muhammad Rohman dan Sofan Amri dapat diartikan sebagai usaha ke arah pencapaian tujuan-tujuan melalui aktivitas-aktivitas orang lain berupa peningkatan minat, perhatian, kesenangan, dan latar belakang siswa (orang yang belajar), dengan memperluas cakupan aktivitas (tidak terlalu dibatasi), serta mengarah kepada pengembangan gaya hidup di masa mendatang. ${ }^{14}$

Dengan demikian dapat diartikan bahwa manajemen pembelajaran adalah sebuah proses perencanaan, pengorganisasian, penggerakan, pengawasan dan evaluasi dalam kegiatan pembelajaran yang dilakukan oleh pengelola pendidikan untuk membentuk peserta didik yang berkualitas sesuai dengan tujuan yang ingin dicapai.

Setiap aktifitas yang akan dilakukan tentu memiliki tujuan yang ingin dicapai, sama halnya dengan manajemen pembelajaran mempunyai tujuan yang ingin dicapai. Dalam hal ini Rohman dan Sofan memaparkan tentang tujuan manajemen pembelajaran secara garis besar sebagai berikut. ${ }^{15}$

a. Untuk mengelola perancangan (desain) pembelajaran.

b. Untuk mengelola implementasi kurikulum pembelajaran.

c. Untuk mengelola pelaksanaan evaluasi kurikulum/pembelajaran.

d. Untuk mengelola perumusan penetapan kriteria dan pelaksanaan kurikulum kelas/kelulusan dalam pembelajaran.

e. Untuk mengelola pengembangan bahan ajar, media dan sumber belajar.

f. Untuk mengelola pengembangan ekstrakurikuler dan ko-kurikuler.

g. Untuk mengelola penerapan uji coba atau merintis pembelajaran yang dicenangkan pemerintah pusat.

Menurut Rohman dan Sofan menegaskan bahwa prinsip-prinsip manajemen pembelajaran adalah sebagi berikut: ${ }^{16}$

a. Produktivitas

${ }^{13}$ Dimyati dan Mudjiono. Belajar dan Pembelajaran. h. 112

${ }^{14}$ Erwinsyah, A. (2017). Manajemen Pembelajaran Dalam Kaitannya Dengan Peningkatan Kualitas Guru. Tadbir: Jurnal Manajemen Pendidikan Islam, 5(1), 69-84.

${ }^{15}$ Dimyati dan Mudjiono. Belajar dan Pembelajaran. h. 121

${ }^{16}$ Hamalik, Oemar, Kurikulum dan Pembelajaran, h. 61 
b. Demokratisasi

c. Kooperatif

d. Efektifitas dan efisiensi

e. Mengarahkan visi, misi, dan tujuan yang ditetapkan dalam kurkulum pembelajaran.

Praktek manajemen menunjukan bahwa fungsi atau kegiatan manajemen seperti planning, organizing, actuating, dan controlling secara langsung atau tidak langsung selalu bersangkutan dengan unsur manusia, planning dalam manajemen adalah ciptaan manusia, organizing mengatur unsur manusia, actuating adalah proses mengerakkan manusia-manusia anggota organisasi, sedang controlling diadakan agar pelaksanaan manjemen (manusia-manusia) selau dapat meningkatkan hasilnya. ${ }^{17}$

Dari fakta di atas dapatlah dibenarkan bahwa pendapat yang menyatakan sukses atau tidaknya suatu organisasi untuk bagian yang besar tegantung kepada orang-orang yang menjadi anggotanya. Betapa pun sempurnanya rencana-rencana, organisasi dan pengawasan penelitiannya, bila orang-orang tidak mau mengerjkan pekerjaan yang diwajibkan atau bila mereka tidak dapat menjalankan tugas yang diwajibkan kepadanya tidak akan diperoleh hasil yang sesuai atau optimal.

Dari uraian di atas dapat disimpulakan bahwa pelaksanaan manjemen pembelajaran merupakan usaha atau mendaya gunakanguru-guru dalam rangka mencapai tujuan pembelajaran dengan langkah-langkah nyata seperti planning, organizing, actuating, sera controlling untuk diterapkan demi mendapatkan hasil yang optimal.

Apa yang harus dikerjakan manajer pembelajaran dalam kaitannya dengan pengembangan manajemen pembelajaran. Sebuah pertanyaan yang tidak bisa dibahas secara ringkas, singkat dan cepat. Sedikitnya diperlukan lima langkah besar dalam rangka pemenuhan target kegiatan tersebut, antara lain: ${ }^{18}$

a. Manajemen atmosfir pembelajaran;

b. Manajemen tugas ajar;

c. Manajemen tugas ajar dalam domain kognitif dan afektif;

d. Manajemen pengajian bahan pembelajaran;

e. Manajemen lingkungan pembelajaran.

Beberapa bagian terpenting dari manajemen pembelajaran tersebut antara lain:

a. Penciptaan lingkungan belajar;

b. Mengajar dan melatihkan harapan kepada siswa;

\footnotetext{
${ }^{17}$ Handoko, T. Hani. Manajemen. Edisi 2 Yogyakarta : BPFE-Yogyakarta, 2001, h.29

${ }^{18}$ Handoko, T. Hani. Manajemen. Edisi 2, h. 33
} 
c. Meningkatkan aktivitas belajar;

d. Meningkatkan disiplin siswa.

\section{METODE}

Jenis dari penelitian ini adalah penelitian evaluatif deskriptif dengan pendekatan kuantitatif. Penelitian evaluatif merupakan suatu desain dan prosedur evaluasi dalam mengumpulkan dan menganalisis data secara sistematis untuk menentukan nilai atau manfaat (worth) dari suatu praktik pendidikan berdasarkan atas hasil pengukuran atau pengumpulan data dengan menggunakan standar atau kriteria tertentu yang digunakan secara absolut maupun relatif. ${ }^{19}$

Penelitian ini dilaksanakan di Madrasah Tsanawiyah Negeri 1 Kota Gorontalo. Subjek penelitian ini adalah seluruh Anggota Sekolah di Madrasah Tsanawiyah Negeri 1 Kota Gorontalo. Dengan rincian sebagai berikut : Kepala madrasah, guru dan tenaga kependidikan, siswa kelas VII sampai kelas VIII.

Instrumen adalah semua alat yang digunakan untuk mengumpulkan, menyelidiki suatu masalah, atau mengumpulkan, mengolah, menganalisa dan menyajikan data-data secara sistematis dan objektif dengan tujuan memecahkan suatu persoalan atau menguji suatu hipotesis. Jadi, semua alat yang mendukung suatu penelitian bisa disebut instrumen penelitian. Dalam penelitian ini menggunakan instrument angket dengan rating scala. ${ }^{20}$

Data atau informasi yang diperoleh dalam penelitian evaluasi ini berasal dari: 1) dokumen yang merupakan syarat administrasi dari suatu program, 2) angket (kuesioner) yang disebarkan kepada narasumber (siswa, kepala sekolah, serta guru), dan 3) wawancara terhadap ketiga narasumber tersebut. Adapun teknik pengumpulan data yang digunakan adalah angket, observasi, wawancara, dan dokumentasi. ${ }^{21}$

Pada penilitian ini analisis data digunakan menentukan kategori atau jenis deskriptif persentase yang diperoleh masing-masing indikator dalam variabel, dari perhitungan deskriptif persentase kemudian dapat di tafsirkan dalam bentuk kalimat. Klasifikasi kategori tingkatan dalam bentuk persentase adalah sebagai berikut:

\footnotetext{
${ }^{19}$ Sugiyono. Metode Penelitian Kuantitatif Kualitatif dan R\&D. Bandung: Alfabeta, 2013, h. 44

${ }^{20}$ Arikunto, Suharsimi. Prosedur Penelitian: Suatu Pendekatan Praktik. Jakarta: Rineka Cipta, 2010, h. 67

${ }^{21}$ Arikunto, Suharsimi dan Cepi Safruddin Abdul. Evaluasi Program Pendidikan: Pedoman Teoretis Bagi Mahasiswa dan Praktisi Pendidikan. 2009, h. 81
} 
Klasifikasi Presentasi

\begin{tabular}{lll}
\hline No & Rentangan & Keterangan \\
\hline 1 & $76 \%-100 \%$ & Baik \\
\hline 2 & $51 \%-75 \%$ & Cukup Baik \\
\hline 3 & $26 \%-50 \%$ & Kurang Baik \\
\hline 4 & $1 \%-25 \%$ & Tidak Baik \\
\hline
\end{tabular}

\section{HASIL DAN PEMBAHASAN}

Evaluasi manajemen pembelajaran di MTs Negeri 1 Kota Gorontalo dapat dilihat dari tiga komponen yaitu perencanaan/persiapan pembelajaran, pelaksanaan proses pembelajaran dan evaluasi/penilaian hasil pembelajaran yang dilakukan, hal itu sesuai dengan model evaluasi yang digunakan yaitu model evaluasi CIPP, yang menekankan pada adanya pelaksanaan dua hal pokok, yaitu (1) kualitas dan (2) hasil, serta membedakan adanya tiga tahap dalam evaluasi program, yaitu (1) anteseden, (2) transaksi, dan (3) keluaran.

\section{Perencanaan Pembelajaran}

Evaluasi terhadap perencanaan pembelajaran atau persiapan (antecedent) pembelajaran yang dilakukan oleh guru dan peserta didik merupakan tahap awal yang menggambarkan kondisi suatu pembelajaran.

Berdasarkan hasil penelitian, diperoleh data bahwa secara umum perencanaan/persiapan pembelajaran di MTs Negeri 1 Kota Gorontalo tergolong baik dengan persentase rata-rata $82.70 \%$. Hasil persentase tersebut diperoleh dari skor keseluruhan yang kemudian dirata-rata untuk memperoleh kesimpulan. Dari tabel evaluasi terhadap perencanaan/persiapan pembelajaran menjelaskan bahwa perencanaan/persiapan pembelajaran yang dilaksanakan di sekolah memenuhi kriteria baik, kesiapan guru dalam melaksanakan pembelajaran dirasa baik sesuai prosedur yang ada. Hal ini dapat dilihat dari perencanaan pembelajaran yang tertuang dalam penyusunan silabus dan Rencana Pelaksanaan Pembelajaran (RPP).

Silabus dan RPP merupakan perencanaan operasional dalam kegiatan pembelajaran yang disusun oleh setiap guru mata pelajaran untuk digunakan sebagai acuan dalam melaksanakan kegiatan pembelajaran. Dalam silabus dan RPP tersebut memperlihatkan bahwa guru telah merencanakan pembelajaran dengan baik, yang dapat dilihat dari isi silabus dan RPP tersebut sudah memuat tentang standar kompetensi, kompetensi inti, indikator, tujuan pembelajaran, materi pembelajaran, metode pembelajaran, langkah-langkah kegiatan pembelajaran, sumber belajar, hingga penilaian yang akan dilakukan. 


\section{Pelaksanaan Pembelajaran}

Pelaksanaan pembelajaran merupakan tahap implementasi atau tahap penerapan atas desain perencanaan yang telah dibuat guru. Evaluasi terhadap pelaksanaan atau proses (transaction) pembelajaran ini meliputi aspek pendekatan dalam pembelajaran, strategi dan taktik dalam pembelajaran, metode dan teknik pembelajaran, serta prosedur pembelajaran.

Berdasarkan hasil penelitian, diperoleh data bahwa secara umum pelaksanaan/proses pembelajaran di MTs Negeri 1 Kota Gorontalo tergolong kategori baik dengan persentase rata-rata $88,59 \%$. Hasil persentase tersebut diperoleh dari skor keseluruhan yang kemudian dirata-rata untuk memperoleh kesimpulan. Tabel evaluasi terhadap pelaksanaan/proses pembelajaran menjelaskan bahwa pelaksanaan/proses pembelajaran yang dilaksanakan di sekolah memenuhi kriteria baik, kesiapan guru dalam melaksanakan pembelajaran dirasa baik sesuai prosedur yang ada. Dalam penelitian ini, peneliti melakukan observasi terhadap guru mata pelajaran di kelas VII dan VIII pada saat pelaksanaan/proses kegiatan belajar mengajar (KBM).

\section{Evaluasi Pembelajaran}

Evaluasi merupakan bagian yang penting dalam setiap kegiatan pembelajaran. Baik tidaknya pembelajaran, berhasil tidaknya pembelajaran dapat diketahui dari evaluasi yang dilakukan. Dalam pelaksanaan pembelajaran, evaluasi tidak hanya dilakukan diakhir kegiatan pembelajaran, namun dapat pula dilakukan pada saat pembelajaran atau yang dikenal dengan evaluasi proses.

Berdasarkan hasil penelitian, diperoleh data bahwa secara umum penilaian/hasil pembelajaran pada peserta didik kelas VII dan VIII di MTs Negeri 1 Kota Gorontalo tergolong baik dengan persentase rata-rata $85,59 \%$. Hasil persentase tersebut diperoleh dari skor keseluruhan yang kemudian dirata-rata untuk memperoleh kesimpulan. Tabel evaluasi terhadap penilaian/hasil pembelajaran menjelaskan bahwa pelaksanaan penilaian/hasil pembelajaran yang dilaksanakan di sekolah memenuhi kriteria baik, penilaian yang diberikan guru terhadap peserta didik dalam kegiatan pembelajaran tergolong baik. Hal tersebut menunjukkan bahwa guru tidak hanya menilai keterampilan peserta didik semata, tetapi juga menilai sikap dan perilaku peserta didik dalam setiap pembelajaran. Kemampuan guru dalam melakukan penilaian terhadap kemampuan peserta didik dalam proses pembelajaran tergolong baik. Tugas-tugas yang diberikan peserta didik juga dinilai dengan maksimal untuk melatih kedisiplinan, sikap dan keterampilan peserta didik dalam pembelajaran. Untuk memotivasi peserta didik, maka penilaian bagi peserta didik aktif bertanya ataupun menjawab dalam proses pembelajaran juga dilakukan.

Hasil menunjukkan pula bahwa guru melakukan penilaian secara praktik diakhir kompetensi dasar yang diajarkan untuk mengetahui sejauh mana penguasaan peserta didik 
terhadap materi yang telah diajarkan. Tidak hanya itu, guru juga terkadang menyampaikan hasil evaluasi secara transparan. Tindakan ini untuk memotivasi peserta didik agar selalu mempertahankan proses belajar bagi yang sudah kompeten dan meningkatkan kualitas belajarnya bagi yang belum kompeten menerima pelajaran. Remedial juga dilakukan terutama bagi yang belum tuntas.

\section{Faktor-Faktor Yang Mempengaruhi Manajemen Pembelajaran MTs Negeri 1 Kota Gorontalo Tahun Pelajaran 2018/2019}

Faktor-faktor yang mempengaruhi pelaksanaan/implementasi manajemen pembelajaran di madrasah meliputi faktor pendukung dan penghambat terhadap jalannya manajemen pembelajaran. Faktor-faktor tersebut dapat berasal dari berbagai segi, baik guru, peserta didik, fasilitas, maupun lingkungan sekitarnya.

Di antara faktor pendukung pelaksanaan manajemen pembelajaran dapat dikembangkan dari kekuatan dalam analisis SWOT yaitu sebuah rekrutmen yang kuat, adanya dukungan dari pimpinan institusi/lembaga, adanya dukungan dari orang tua yang baik, dan tersedianya fasilitas belajar yang memadai.

Faktor penghambat pelaksanaan manajemen pembalajaran pun dapat dikembangkan dari kelemahan atau hambatan dalam analisis SWOT yaitu kebalikan dari kekuatannya, antara lain dari segi peserta didik misalnya terdapat beberapa input peserta didik yang kurang bagus, faktor fisiologis peserta didik saat belajar; dari segi guru seperti kurangnya staf pengajar berkualitas; berkurangnya dukungan dari pimpinan; masih ada fasilitas yang kurang; orang tua peserta didik yang hanya menuntut hasil belajar segi kognitifnya saja.

\section{KESIMPULAN DAN SARAN}

\section{A. Kesimpulan}

Berdasarkan hasil penelitian dan pembahasan mengenai evaluasi manajemen pembelajaran di MTs Negeri 1 Kota Gorontalo, diperoleh simpulan sebagai berikut:

1. Perencanaan pembelajaran di MTs Negeri 1 Kota Gorontalo yang meliputi perencanaan pengelolaan kegiatan pembelajaran (penyusunan silabus dan RPP), perencanaan bahan pembelajaran, perencanaan pengelolaan kelas, dan perencanaan penilaian prestasi belajar peserta didik dikategorikan baik (82.70\%).

2. Pelaksanaan proses pembelajaran di MTs Negeri 1 Kota Gorontalo yang meliputi pengelolaan ruang, waktu, dan fasilitas, penggunaan metode pembelajaran, penguasaan materi pembelajaran, penggunaan sumber/media pembelajaran, pengelolaan interaksi kelas, 
pemberian tugas, dan pemberian umpan balik secara keseluruhan telah berjalan dengan baik $(88.59 \%)$.

3. Evaluasi/penilaian hasil pembelajaran di MTs Negeri 1 Kota Gorontalo yang meliputi pelaksanaan penilaian pembelajaran, penilaian perilaku peserta didik dalam pembelajaran, dan hasil dari pembelajaran itu sendiri telah berjalan dengan baik (85.59\%).

4. Secara keseluruhan evaluasi terhadap manajemen pembelajaran di MTs Negeri 1 Kota Gorontalo dari segi perencanaan, pelaksanaan proses pembelajaran, dan evaluasi/penilaian hasil pembelajaran tergolong baik dengan perolehan rata-rata $85.63 \%$.

5. Faktor yang mempengaruhi pelaksanaan manajemen pembelajaran di MTs Negeri 1 Kota Gorontalo

Faktor yang mempengaruhi pelaksanaan manajemen pembelajaran meliputi faktor pendukung dan penghambat. Diantara faktor pendukung pelaksanaan manajemen pembelajaran adalah adanya sebuah rekrutmen pendidik yang kuat dengan ditetapkan syarat tertentu untuk seleksi, dukungan dari pimpinan, dukungan orang tua peserta didik, dan ketersediaan fasilitas yang cukup memadai. Sementara itu juga terdapat faktor yang menghambat yang berasal dari peserta didik, seperti adanya beberapa input yang kurang baik serta faktor fisiologis peserta didik. Faktor yang berasal dari pendidik, antara lain terbatasnya jumlah pendidik karena sulitnya memperoleh sosok pendidik yang sesuai dengan kualifikasi pendidikan yang tepat sehingga jumlah yang ada tidak seimbang dengan jumlah peserta didik yang dibina. Selain itu penghambatnya adalah adanya beberapa pihak dilingkungan sekitar yang belum bisa menerima keberadaan madrasah, masih adanya fasilitas yang kurang, serta tuntutan aspek kognitif yang lebih dominan.

\section{B. Saran}

Berdasarkan hasil dan pembahasan yang diperoleh dalam penelitian ini, maka peneliti memberikan saran antara lain:

1. Penyelenggaraan manajemen pembelajaran dengan ciri khas madrasah atau keislaman hendaknya lebih ditingkatkan dan dimantapkan.

2. Pelaksanaan pembelajaran di MTs Negeri 1 Kota Gorontalo pun sebaiknya lebih ditertibkan, dilaksanakan sesuai dengan jadwal yang telah ditetapkan, dan kedisiplinan yang sudah ditetapkan hendaknya diterapkan dengan sungguh-sungguh sehingga tujuan dari MTs Negeri 1 Kota Gorontalo yang diinginkan dapat tercapai.

3. Bagi Peneliti selanjutnya, agar dapat melakukan penelitian kualitatif, upaya untuk menggambarkan permasalahan tentang manajemen pembelajaran 


\section{DAFTAR RUJUKAN}

Ahmad, Zainal Arifin. (2012). Perencanaan Pembelajaran: dari Desain sampai Implementasi. Yogyakarta: PT Pustaka Insan Madani.

Arifin, Zainal. (2010). Penelitian Pendidikan: Metode dan Paradigma Baru. Bandung: PT. Remaja Rosdakarya.

Arikunto, Suharsimi dan Cepi Safruddin Abdul. (2009). Evaluasi Program Pendidikan: Pedoman Teoretis Bagi Mahasiswa dan Praktisi Pendidikan.

Arikunto, Suharsimi. (2010) Prosedur Penelitian: Suatu Pendekatan Praktik. Jakarta: Rineka Cipta.

Arikunto, Suharsimi. (2009). Dasar-dasar Evaluasi Pendidikan. Jakarta: Bumi Aksara.

Arikunto, Suharsimi. (1996). Prosedur Penelitian: Suatu Pendekatan Praktek. Jakarta: Rineka Cipta.

Azwar, Saifuddin.(1995). Sikap Manusia, Teori dan Pengukurannya. Yogyakarta : Liberty.

Calhoun, J.F dan Joan Ross Acocella. (1995). Psikologi Tentang Penyesuaian dan Hubungan Kemanusiaan. Semarang : IKIP Semarang.

Darsono. (2000). Belajar dan Pembelajaran. Semarang : IKIP Semarang Press.

Daryanto, H.M. (2006). Administrasi Pendidikan. Jakarta : PT. Rhineka Cipta.

Destianingtyas. (2013). Evaluasi Pelaksanaan Pembelajaran Keterampilan Komputer dan Pengelolaan Informasi (KKPI) Pada Siswa Kelas XI di SMK Texmaco Pemalang. Skripsi. Semarang: Fakultas Ilmu Pendidikan Universitas Negeri Semarang.

Dimyati dan Mudjiono. (2002). Belajar dan Pembelajaran. Jakarta : Rineka Cipta.

Elis Ratnawulan dan Rusdiana. (2015). Evaluasi Pembelajaran. Bandung: Pustaka Setia.

Erwinsyah, A. (2017). Manajemen Pembelajaran Dalam Kaitannya Dengan Peningkatan Kualitas Guru. Tadbir: Jurnal Manajemen Pendidikan Islam, 5(1), 69-84.

Hamalik, Oemar. (1995). Kurikulum dan Pembelajaran, Jakarta : Bumi Aksara.

Handoko, T. Hani. (2001). Manajemen. Edisi 2 Yogyakarta : BPFE-Yogyakarta, 2001.

Hariwijaya, M. (2007). Metodologi Dan Teknik Penulisan Skripsi, Tesis, Dan Disertasi. elMatera Publishing. Yogyakarta.

Majid, Abdul. (2011). Perencanaan Pembelajaran: Mengembangkan Standar Kompetensi Guru. Bandung: PT. Remaja Rosdakarya Offset.

Muhammad Rohman. (2012). Manajemen Pendidikan (Analisis Dan Solusi Terhadap Kinerja Manajemen Kelas Dan Strategi Pengajaran Yang Efektif). Jakarta : PT Prestasi Pustakarya.

Oemar Hamalik. (1995). Kurikulum dan Pembelajaran. Jakarta : Bumi Aksara.

Purwanto. (2009). Evaluasi Hasil Belajar. Yogyakarta : Pustaka Pelajar. 
Rahayu, E. F. (2015). Manajemen Pembelajaran dalam Rangka Pengembangan Kecerdasan Majemuk Peserta Didik. Manajemen Pendidikan, 24(5), 357-366.

S.P Hasibuan, Malayu. (2006). Manajemen Dasar, Pengertian, dan Masalah,Edisi Revisi. Jakarta: Bumi Aksara.

SS, Y. S. D., \& SE, M. (2013). Manajemen pembelajaran dalam upaya meningkatkan mutu pendidikan. Jurnal Mimbar Bumi Bengawan, 6(13).

Sugiyono. (2013). Metode Penelitian Kuantitatif Kualitatif dan R\&D. Bandung: Alfabeta.

Sugiyono. (2010). Metode Penelitian Pendidikan: Pendekatan Kuantitatif, Kualitatif, dan R\&D.Bandung: CV. Alfabeta.

Syaiful Sagala. (2003) Konsep dan Wacana Pembelajaran. Bandung: Alfabeta.

Syarifudin. (2005). Administrasi Pembiayaan Pendidikan. Bandung : CV. Pustaka Setia.

Tabrani Rusyan dkk. (2000). Upaya Meningkatkan Budaya Kinerja Guru, Cianjur: CV. Dinamika Karya Cipta,

Widoyoko, Eko Putro. (2011). Evaluasi Program Pembelajaran; Panduan Praktis Bagi Pendidik dan Calon Pendidik. Yogyakarta: Pustaka Pelajar. 